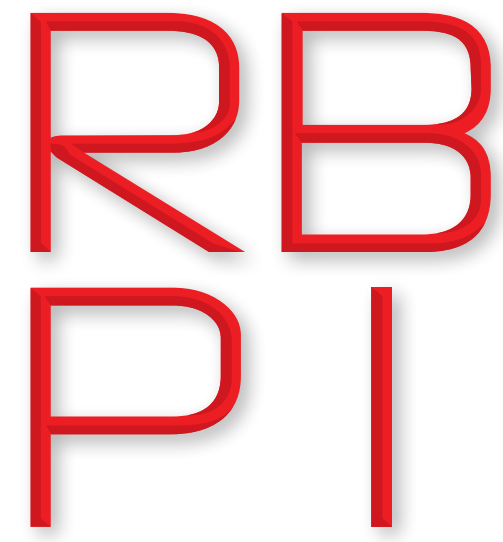

Revista Brasileira de Política Internacional ISSN 1983-3121

http://www.scielo.br/rbpi

\section{Daniel Buarque ${ }^{1}$}

${ }^{1}$ King's College London, Brazil Institute, London, United Kingdom of Great Britain and Northern Ireland.

(dbuarque@gmail.com)

ORCID ID: orcid.org/0000-0002-1266-9022

\section{Copyright:}

- This is an open-access article distributed under the terms of a Creative Commons Attribution License, which permits unrestricted use, distribution, and reproduction in any medium, provided that the original author and source are credited.

- Este é um artigo publicado em acesso aberto e distribuído sob os termos da Licença de Atribuição Creative Commons, que permite uso irrestrito, distribuição e reprodução em qualquer meio, desde que o autor e a fonte originais sejam creditados.

\title{
A country on the fence: United Kingdom's perceptions of the status and international agenda of Brazil
}

DOI: http://dx.doi.org/10.1590/0034-7329202000112

Rev. Bras. Polít. Int., 63(1): e012, 2020

\section{Abstract}

Brazil has long strived for greater status and a stronger role in international politics, but its actual standing depends on the recognition it gets from outside. This paper analyses the perceptions of the status of Brazil from the perspective of the UK. It contributes both to the study of status in IR (by using a qualitative method with focus on perceptions and inter-subjectivity) and to the study of the status of Brazil (by analysing external perceptions about its standing in the global hierarchy). Based on interviews with British diplomats who served in Brazil, it shows that the UK believes the country misperceives its own place in the world and appears to remain "on the fence" in global affairs.

Keywords: Status; Prestige; Recognition; Perception; Brazil; Brazil-UK relations; Diplomacy.

Received: April 23, 2020

Accepted: August 03, 2020

\section{Introduction}

$\mathrm{B}$ razil's quest for increased international status is well documented and is understood as part of the history of the diplomacy of the country (Ricupero 2017; Lafer 2001; Carvalho 2020; Diaz and Almeida 2008; Larson and Shevchenko 2014a; Stuenkel and Taylor 2015; Mares and Trinkunas 2016; Stolte 2015). The Brazilian foreign policy community sees a stronger international role for the country as one of the priorities of the nation (Souza 2008; 2002). Many of the country's international strategies have been associated with this drive for more prestige globally, such as the long-standing bid for a permanent seat on the United Nations Security Council (UNSC) (Andrade 2012; Garcia 2011; Vargas 2008; Arraes 2005; Mendes 2015). Its approach towards a closer relationship with Africa (Stolte 2015), 
its participation in peacekeeping operations (Kenkel et al. 2020; Hamann and Jumbert 2020), its strong position in international debates (Hamann and Jumbert 2020; Ricupero 2017; Lafer 2001), its role in multilateral fora such as BRICS and IBSA (Pant 2013; Hurrell 2010; Larson 2019), and even its environmental leadership have all been analysed as part of this drive for more international prestige and recognition (Stuenkel and Taylor 2015; Chatin 2016).

Although a great deal has been said about the ambitions of Brazil, and the "emergence" of the country, little is really known about the actual status of Brazil in the world. Even if the country wants to be an important player in the international sphere, nations depend on other states to become the kinds of actors they want to be, and it is not possible to achieve status without recognition (Wohlforth et al. 2018; Murray 2019; 2010; Clunan 2014; Paul and Shankar 2014; Lebow 2008; Duque 2018; Wohlforth 2014; Wolf 2011; Neumann and Carvalho 2014).

In order to better understand the actual situation of the country in relation to the global hierarchy, this paper offers a contribution both to the study of status in IR and to the study of the international standing of Brazil. It develops a qualitative assessment of the status of the country and of its foreign policy agenda based on the perspective of the perceptions held by the British Foreign and Commonwealth Office (FCO), the UK's department of foreign relations. The study employs a reflexive thematic analysis of semi-structured interviews with six current and former members of the FCO who have worked in Brazil and who have participated closely in the development of British policy towards Brazil. It supplements the literature on the subject by examining the intersubjective character of status through the perceptions of members of the foreign policy community of one of the countries that hold a higher position in the global hierarchy. It looks at Brazil through the eyes of the people making foreign policy in the United Kingdom, one of the permanent members of the UNSC, and a country that holds the keys to that club of countries with greater status than Brazil. It is important as a first step in understanding status not from the study of the strategies used by Brazil, but trying to measure the country's status according to the perception of a nation of higher status. Based on the analysis of these interviews, the paper shows that, from the UK perspective, Brazil seems to misperceive its international role, and the emergence of the country may have been hindered by an avoidance of taking sides in global issues.

Conflicting studies have depicted Brazil both as a new powerhouse, even without military strength (Chatin 2013), and as a leader without any followers (Malamud 2011). This is actually part of the main perceptions of Brazil in the rest of the world, showing that there are many ambiguities in the images of the country (Mariutti and Tench 2016; Mariutti et al. 2017). Recent research has tried to develop methods of evaluating this status with a quantitative approach. Duque (2018) and Beaumont and Røren (2020) have applied analysis of diplomatic representation as a means of assessing this status. Other analyses have focused on the perceived image of Brazil among the general public of other nations, such as nation branding surveys, which show that the rest of the world does not see it as a "serious country" (Buarque 2019). Studies have assessed the projection of stereotypes of the country on the international media (Buarque 2015), on international cinema (Amancio 2000) and the general image of tourism (Bignami 2002; Kajihara 2010; Buarque 2017). 
However, there has not been a great deal of research focusing on the intersubjective character of status in IR by analysing perceptions of external parties, such as the beliefs in the foreign policy community about Brazil specifically. It is an important approach, since status depends on recognition from other countries (especially those that already have higher status) and not only on the drive of a nation to achieve it. Thus, the perceptions held by the foreign policy community in countries that actually hold international power and prestige may not necessarily be the same as the image Brazil is trying to project and achieve in global relations (Larson and Shevchenko 2014b; Renshon 2017).

This analysis of the perceived status of Brazil and the international agenda of the country according to British diplomats draws from this recently developed scholarship of status in international relations. The approach discusses the social and psychological relations that lead to the idea of status and reinforces the importance of subjectivity and perception to the debate about the standing of one nation in comparison to others, breaking away from more traditional and quantitative measures of power capabilities. It starts by discussing the development of theories of status in international relations (IR), the importance of intersubjectivity and of perceptions for this approach to IR. Next, it addresses the methodological challenges of studying status in IR and describes the use of reflexive thematic analysis as a method to take this analysis forward. Finally, the paper presents the main findings in the analysis of the interviews, showing that British diplomats see Brazil as a country that misperceives its own place in the global hierarchy, that it seems to avoid commitment, and often appears to be "on the fence".

\section{Status in International Relations}

The focus on status is a recent development in the theories of international relations. Looking back at the scholarship of IR, however, it is possible to see that scholars have always sensed that besides the traditional focus on power hierarchies, prestige and status were also important, although it was not traditionally the focus of rigorous analysis (Paul et al. 2014; Renshon 2017; Markey 1999). From the beginning of the formation of a European system of states, the different nations were already considered to belong to different layers whose power and importance varied, hinting at the origins of the ideas of prestige and status (Neumann 2014).

While international politics generally assumes that it operates under conditions of anarchy and equality, this does not explain variation in international political conditions. As Renshon $(2017,1)$ proposes, "the fundamental ordering principle of international politics is hierarchy, not equality". Furthermore, Markey (1999) argues that it is possible to see disputes over prestige as the origin of international conflicts, even from a realist perspective. Realist scholars such as Morgenthau and Waltz mention that prestige and status were important as a way to differentiate states according to their level of power, especially the role and importance of great powers (Volgy et al. 2011; Markey 1999). Status is also present in the perspective of the English School, and in constructivist theories, 
leading to the idea that there are variations in the way states deal with one another and how they are ranked (Wendt 1992; Volgy et al. 2011; 2014). More recently, a new approach focused on the importance of status in inter-state relations, borrowing from Social Identity Theory (SIT) and social psychology, and using national identification and comparison with other nations as the basis for the search for status (Larson and Shevchenko 2019; 2014a).

The very definition of status in IR and the development of ways to measure it borrows from disciplines like sociology and psychology. It steps away from simple measures of power capabilities and leads to a recognition of the intersubjective aspect of status, and to the challenges of applying it to new studies. This paper follows the definition developed by Paul et al. (2014, 7), which states that status is the "collective beliefs about a given state's ranking on valued attributes (wealth, coercive capabilities, culture, demographic position, sociopolitical organization, and diplomatic clout)". Since status reflects collective beliefs, this makes the concept highly intersubjective. It is not a reflection of a state's material attributes, but depends on others' perceptions. It refers to higher order beliefs about a state's relative ranking. It refers to "beliefs about what others believe" (Paul et al. 2014, 8). The intersubjective, relational characteristic of status is one of the main points of the literature on this approach. Status attribution has been described as a perceptual phenomenon with behavioural consequences (Volgy et al. 2011).

The main focus of the scholarship of status in IR is on possible disputes between powerful nations, which could end up leading to conflict and wars. However, Neumann and Carvalho (2014) have shown that status is a key driver in the policies of smaller states (or emerging powers, like Brazil) in the everyday life of international society. The authors take the focus away from the relation between status and conflict and show that lesser powers suffer from status insecurity and attempt to improve their international standing through the routine of institutionalised diplomatic exchanges. For these less powerful countries, recognition of status is fundamental, and their strategies guided their social dealings with other states in the everyday life of international politics (Wohlforth et al. 2018).

Most studies of status in IR focus more on status aspirations and in the attempt to develop quantitative methods to measure status. This is often self-referencing and lacks analysis of the matter through the eyes and subjective perceptions of third parties, such as analysis of the foreign view of Brazil and its status (Renshon 2017; Duque 2018; Beaumont and Røren 2020; Mares and Trinkunas 2016). Duque (2018) and Beaumont and Røren (2020) have applied analysis of diplomatic representation as a means of understanding this status with a quantitative approach. Although most studies of status use this approach, the method has limitations and seems to capture a state's military or economic power more than how much it is admired (Mercer 2017). Using the relative level of received diplomatic representation as a proxy for status recognition is limited by the use of diplomatic missions in practice by great powers, due to the fact that embassies tend to change slowly and by anomalies caused by peculiar state-specific factors. Quantitative analysis alone might not be enough, and qualitative interpretations are important to the scholarship of status (Røren and Beaumont 2019). 
Qualitative studies of perceptions of status are also important because the asymmetries of prestige can be fuzzy, due to incomplete agreements on the relative importance of nations' attributes (Wolf 2019). By focusing on the intersubjective character of status, this paper analyses the perception of foreign stakeholders in order to advance this qualitative approach to understand status, and fills this gap in the scholarship. This assessment, based on semi-structured interviews, offers the advantage of being more open-ended, allowing a more in-depth study of the collective beliefs of the actors that are part of the community that can offer recognition of status to an aspiring country like Brazil.

Research traditionally discusses status based on the foreign policy interest of nations and ends up becoming too self-referencing. The fact that nations use their own sense of pride as evidence of their status can lead to the interpretation that prestige is a psychological illusion with no strategic or intrinsic value (Mercer 2017). One of the main points of this criticism is related to problems in the way status can be assessed. On one hand, it is important to consider that the status of a nation depends on what a community of observers thinks about one specific actor - and not what the actor thinks about itself (Mercer 2017). But there are not a lot of studies about status in international relations through the eyes and perceptions of third parties, nor analyses of the foreign gaze towards one country and its status.

This paper offers a contribution to the scholarship of status in international relations by focusing on a qualitative approach on the perceptions of a foreign policy community in a nation with higher status. Even if the focus is on the subjective perception of a small group of diplomats, it offers a new and different qualitative perspective to evaluate Brazil's international status.

Although status is a rather symbolic attribute, there are limitations to measuring it through perceptions alone (Renshon 2017). As a social artefact, status is social reality in itself. And, as much as beliefs and perceptions may matter in politics, as an intersubjective category, status cannot be reduced to either, and notions of prestige and hierarchy only make sense as part of larger structures of meanings (Pouliot 2014). Another matter that needs to be addressed is the question of whose perception is being analysed in a study about status. Although surveys about perceptions of "images" of nations are becoming more popular in the world, Jiménez-Martínez (2018) explains that it is important to think about which foreign view is directed to which nation and in what context this is being analysed. For this paper, the focus is on British diplomats who represent the FCO and discuss their perceptions about the international agenda of Brazil from 1989 to 2014.

These opinions are important in revealing the perception of a sample of the British foreign policy community, and they do help understand the status of Brazil according the UK, but it is important not to take these subjective views as the actual standing of Brazil in the global hierarchy. On one hand, the views represent the perceptions from one country, rather than Brazil's status more broadly. At the same time, it is important to recognise that the views are embedded in the a dispute for the so-called international pecking order, and that they can be biased towards the interests of the nation they represent (Pouliot 2016). 
Another important caveat of the approach used here is that studies of status in IR can be criticised for essentialising the state, which ultimately leads to approaching it as a unitary actor (Kaczmarski 2019). Many contemporary studies have tried to avoid this pitfall and have proposed the idea that states are formed by multiple agents. They would, therefore, perceive the thought of a country as a single entity, or even the perspective of this identity as singular, as too simplistic. Nevertheless, most works in international relations theory do use the state as a unity of analysis. Wolfers (1962) argues this approach is the "traditional" line in IR, and Wendt (2003, 215) goes as far as arguing that "states are people too". The author defends the use of the nation as a unity in international relations analysis, since they are purposive actors, and argues this is a useful instrument for organising experience and building theory (Wendt 2004). Since this study seeks to understand perceptions of Brazil's status based on interviews with diplomats, and considering diplomats tend to treat Brazil as a unitary actor, that is part of the empirical findings, and it makes sense to consider their perceptions of the country as a whole.

It is true that there are limitations to understanding status through perceptions, but it is difficult to completely downplay the importance of the latter for the former. Ignoring beliefs and perceptions is equivalent to thinking of the international reality as an environment free of subjectivity and based on unreal objectivity. The beliefs of the foreign policy community of a country are fundamental to the political decisions taken by that country, so subjectivity plays a large role in defining the realpolitik of nations. Although it is true that perception is not everything, it is also important and should be considered. In order to know a state's status, it is necessary to estimate the collective recognition of such state by other relevant states (Wohlforth 2014). Any method to try to understand the status of a nation is fraught with ambiguity, and states face strategic incentives to misrepresent their beliefs. However, the research presented in this paper uses semi-structured interviews with experts who make up the foreign policy community of the $\mathrm{UK}$ as the means to try to understand the status of Brazil.

\section{Research design}

The importance of status and prestige in global affairs has become a more relevant approach in the international relations scholarship in recent decades. However, measuring status is something that is deemed to be a challenge, since the concept is relational and is also connected to intersubjectivity and perception (Clunan 2014; Lake 2014; Larson and Shevchenko 2010; 2014a; 2014b; Larson 2019; Lebow 2016; 2008; Paul et al. 2014; Stuenkel and Taylor 2015; Diaz and Almeida 2008; Renshon 2017). There is an important gap in this scholarship, and a lot is still unknown in regard to status, as most studies in the area are based on intuition, not evidence (Renshon 2017, 3). Mercer (2017) argues that the focus on quantitative studies has led to an absence of qualitative evidence about prestige in international relations, which can lead to skepticism of the traditional view on prestige. 
Many authors argue that IR seems to lack a methodological standard, which is partly justified by epistemological divides within the field. Therefore, applying methods from other areas of scholarship to IR research can be a good resource (Klotz 2008). While the analysis of Brazil's status mostly draws on quantitative approaches, this paper borrows its method from psychology to advance the analysis of the intersubjective character of status and the perceptions of the country's standing from an external perspective, in order to offer a contribution to this scholarship. It applies reflexive thematic analysis (Braun and Clarke 2013), a method still not widely used in IR, but which helps fill a gap in the qualitative approaches to assess status.

Qualitative research is interested in meaning and uses words as data, in contrast to quantitative research, which uses numbers as data and analyses them using statistical techniques. This paradigm tends not to assume there is only one correct version of reality or knowledge, and accepts that there are multiple versions of reality. Therefore, the analysis of qualitative data tells one story among many that could be told about the same data (Braun and Clarke 2013). In the analysis presented here, this means that the qualitative analysis of six interviews offers one sample of the interpretation the FCO makes of the international agenda and the status of Brazil, but other perceptions could be found in interviews with different informants and analyses by other researchers (Barkin 2008).

This method was selected in order to provide a qualitative assessment of Brazil's standing in a way that would focus on the intersubjective character of status. Since the prestige of one country is based on the collective beliefs of a community, but grasping and analysing collective beliefs holds methodological challenges, one way of trying to understand this phenomenon can be to understand the subjective perception of actors involved in the international relations between the countries considered. It is true that this leads to other limitations. Although intersubjective beliefs differ from subjective evaluations, collecting and developing a systematic and reflexive thematic analysis of different individual subjective perceptions can help paint a broader picture of the beliefs about the prestige of Brazil (Mercer 2017).

Another limitation is that status is generally thought of in a broader intersubjective context, so that it would be defined not only from the perspective of one country (the UK, in this research), but in the collective beliefs of many (if not all) countries in the world. Although this really limits the analysis presented here, understanding the perceptions of status from at least one other country - especially one that is among the powers that hold permanent seats at the UNSC - is one important step in acknowledging that these foreign perceptions matter for international status. It also helps to understand the external views about the standing of Brazil in international relations.

The data corpus used in this analysis is formed of six interviews with current and former members of the Foreign and Commonwealth Office, the British department of foreign relations. The sample was selected to be representative of the British international relations community. Of the six interviewees, three have been British ambassadors to Brazil, and two others have been consuls of the UK in Sáo Paulo. Although this may seem as a limited sample, the interviewees have extensive experience working in Brazil and helping develop British policy towards the 
country, and are likely the sources of a lot of the official interpretation of Brazil among the UK foreign policy community. The former ambassadors interviewed represented London in Brazil for more than 12 years, so they are relevant to understanding British beliefs in regard to the country. Even if they do not represent all different perspectives of British diplomats, they do offer interesting insights, complementing the interpretation of one another and even disagreeing in some points. They allow us to assess the perceptions of the British foreign policy community of Brazil.

The interviews were conducted between March 2018 and March 2019. The informants were asked about their perceptions of Brazil, their experience in the country, the image of the country in their own nation, their perceptions about the international agenda and the interests of Brazil in global affairs, as well as the role of the country, its status and what they thought the country could achieve internationally. The data collected in these semi-structured interviews was transcribed, anonymised and analysed using NVivo software, as well as reflexive thematic analysis as a method. Thematic analysis (TA) is one of the most common approaches to qualitative data analysis (Bryman 2012). Since the early 2000s, the method has been further developed, and its process has become more attached to a qualitative and reflexive approach. With a closer relation to psychology studies, Braun and Clarke (2013) developed a new step-by-step guide to conducting TA as a qualitative method. They proposed a blueprint of how to conduct thematic analysis, with six basic steps for the method: 1. Familiarisation with the data; 2. Generating initial codes; 3. Searching for themes; 4. Reviewing themes; 5. Defining and naming themes; and 6. Producing the report. From this reflexive analysis, it was possible to develop the findings discussed in the following section.

\section{The status of Brazil according to the UK}

Although Brazil has been pursuing status for decades, the struggle has been frustrating, and the country has not been accepted as a peer among great powers (Carvalho 2020). With a relational approach based on a quantitative analysis of a network of embassies, Duque (2018) shows that Brazil is out of the main circle of powers of the world. With a similar approach, Beaumont and Røren (2020) showed that Brazil underperforms in terms of status since the redemocratisation. As Mares and Trinkunas (2016) observe on their analysis of the international ambitions of Brazil, the country has often fallen short of acquiring more status. At the same time, international surveys point to the idea that Brazil is perceived by the general public in the rest of the world as a country that is not serious (Buarque 2019). These aspects of the image of the country as focusing on stereotypes of exoticism and on leisure are also reinforced by studies of the reputation of the country in tourism and in international cinema (Bignami 2002; Amancio 2000).

From the point of view of members of the British department for foreign relations, Brazil does have a great deal of potential, but this potential has been unfulfilled for decades, as the 
nation does not seem to have a clear role in global politics. The analysis of the interviews shows that the FCO's perception is that Brazil misperceives its own place in the world and believes it is more relevant to international politics than it really is. In their view, this is in part caused by the fact that the country has many internal problems. It is too inward looking and is largely unknown in other parts of the world. Also, there is an apparent lack of commitment to support any side in different international disputes. The country often defends neutrality, but as a result appears to be "on the fence", undecided about which side it will support. This hinders its attempt at emergence. From the perception of British diplomats, Brazil does not appear to really know what it wants to achieve, apart from its search for status, recognition and a permanent seat at the UNSC. As a result, the country is not perceived as particularly relevant in important global issues. Brazil, the analysis of the perceptions of the British diplomats shows, "wants to be friends with everyone", as one of the interviewees (UK3) explained, and the result is it does not have a clear place in the world.

As previously explained, these findings reflect the patterns and insights developed from the reflexive analysis of the interviews. Although the method applied in the research did not focus on the prevalence of themes, the idea of Brazil not taking sides in international politics and the effects of that in limiting its role in the world was one of the most interesting points, mentioned in all of the interviews.

The idea of someone being on the fence is often used to represent indecisiveness. However, in the case of Brazil, the perception of the British diplomats is not that the country is undecided, but that it is unwilling to support one side or another in order to avoid commitment. Offering a position of neutrality is in fact just a way of not becoming too involved. It is based on the "unwillingness of Brazil to intervene on one side or the other", as one of the members of the FCO (UK3) explained.

Volgy et al. (2014) explain that status provides states with added influence, but also creates additional pressures to pursue policies and interests outside their immediate neighbourhoods. Higher status brings expectations that these states will exercise leadership on a variety of issues and conflicts central to international or regional politics. The interviews analysed show that the foreign policy community of a powerful nation does not think that Brazil is ready to accept this kind of responsibility, even if it does seem to want to be a great power.

From the perspective of British diplomats, Brazil is often uncommitted to any specific position in international affairs, which makes it appear unwilling to take sides, or to want to make any decision. This is seen as a problem because Brazil aspires to a role of leadership in the world. The countries that actually are great powers have to make decisions and take sides. "If you are going to be a world power, being the 5th, 6th largest economy in the world and want the political influence to go with that, you need to be prepared to take sides", said one of the sources of this study (UK3).

As interviewee UK3 described, given that countries operate their foreign policy and international affairs on the basis of self-interest, if Brazil wants to obtain the political respect that 
it is seeking, "it should be prepared to take sides more often". Another of the British diplomats (UK4) argued that Brazil has a lot of potential, power and strength, "but it is too scared, too frightened, to upset people, take sides. It should be a bigger player than it is, but because of its reluctance to get involved, it ends up weak".

This ambivalence is in line with what is described by Carvalho (2020) as a problematic strategy of hybridism. Brazil sought to have its status claims recognised both by the global north, especially the great powers, and by its southern peers, which makes it be seen as uncommitted to any of the sides. "They don't want to take sides, [and it] means that they end up doing more harm than good", diplomat UK4 argued. According to the perception of the members of the FCO, this is an indication that Brazil does not seem to be completely clear about what it really wants to achieve and the role it seeks to have in the world. This shows "a contradiction between what they say they want and what they will find in practice if they do that", interviewee UK4 said. "Brazil wants to be seen as a leader without actually having to lead anything", the source argued.

In line with some of the findings in this study, Larson and Shevchenko (2014a) explain that this ambition for international status will force Brazil to take positions in which it is clear that the country is accepting international responsibilities. If Brazil wants support for its bid for a permanent seat at the UNSC, for example, it will need to take responsible positions on global governance issues rather than abstaining.

It is important to note that these perceptions of Brazil might have been influenced by the political context of the period when the interviews were conducted. Although the conversations were directed to a discussion about the international agenda of Brazil from 1989 to 2014, the political situation of the country in 2018 was of polarisation and change, with the campaign that led to the election of Jair Bolsonaro for the Presidency. The context could also influence the perception of Brazil being on the fence. During the period of the data collection, UK-Brazilian relations were strained by the poisoning of Sergei and Yulia Skripal in Salisbury in March 2018. The UK blamed the Russian government for the poisonings but Brazil avoided condemning Russia. This could have been interpreted as one of the situations in which the country appeared to be "on the fence". In fact, one of the diplomat informants of the study (UK5) mentioned the Salisbury case as an example of Brazil not taking sides. "I imagine the current British ambassador has had quite a tough time over the issue of the Salisbury attack, for example, where, in its usual way, the Itamaraty will not point a finger to blame anybody, because it doesn't do that. It is not what it does in international relations".

The analysis of interviews with British diplomats also shows that their perception does not match what Brazil expects to be its status, and that they believe the country misperceives its own place in the world. This could be equivalent to saying that, from the perspective of the FCO, Brazil is not recognised as an important player in international politics, which is fundamental for status.

According to the interviewees, this misperception leads to a policy that sometimes overstretches the real capabilities of Brazil. British diplomats believe that Brazil projects the idea that it is 
destined for greatness. Although this could be expected for a distant future, the perception of the interviewees is that Brazil believes it should have a great deal of status regardless of the country's actual present capabilities. This leads to hubris and to the country overplaying its hand in international negotiations - even if it avoids taking sides.

This idea of misperception is one of the most well developed in the theories related to status in IR. It is understood as one nation's will to be recognised as having a higher status, while other countries see it as having lower status (Larson and Shevchenko 2014a; Murray 2019). According to the perception of the British diplomats, this misperception Brazil has of itself is shown in cases like the negotiations with Iran, a situation where they say Brazil should not have been involved, but did anyway, which surprised diplomats closer to the negotiation. According to one of the interviewees, the negotiations with Iran are an example of Brazil overplaying its hand.

This misperception is also seen as relevant in the Brazilian attempt to become a permanent member of the UNSC, as this affiliation to a "club" is often described in the literature as one of the main symbols of international recognition and prestige (Volgy et al. 2011; Larson and Shevchenko 2019). Although this was perceived by the diplomats interviewed here as a rare example of a consistent international agenda for Brazil, the permanent seat is seen as something that should reflect the real status of a nation, and not just the will to have more prestige. The UK officially supports the country's bid, and the diplomats interviewed in this study argued that the UK wants to see Brazil develop a strong international voice and assume a permanent role in the Council. However, the perception of the FCO is that it is not something Brazil will achieve, because of its own limitations, because of huge costs connected to it and because of external constraints. One of the main points repeated by the interviewees was that this is one target that Brazil has always had, will always have and will never achieve. This confirms what the literature about status in IR says about groups that have higher status wanting to maintain their position. As Larson and Shevchenko (2014a) explain, the higher-status group is more likely to acknowledge the out-group's accomplishments if it believes that its own position is legitimate and secure.

When the interviewees discussed the Brazilian bid for a UNSC permanent seat, it often led to the idea that expanding the number of permanent members would dissolve the power of nations that want to keep themselves above the nations that want more status. Therefore, they tend not to recognise the aspiring countries, making it more difficult to go forward with reforms. The main reason why the Security Council has not been enlarged is because there are permanent members who want to maintain the status quo. "It is not a question of whether they want Brazil or not. They don't want anybody", interviewee UK5 argued. The British diplomats interviewed defended the official UK position of supporting Brazil's bid. But they admitted it is a comfortable situation for the UK. It does not have to actually give up anything, since it will not happen. They also argued that Brazil has to do more to be able to achieve the position of a great power and, most of all, must be ready to pay the price that comes with this higher status.

Although the interviews reveal the intersubjective character of the status of Brazil, and offer interesting insights to understand the general standing of the country in the global order, it is 
important to understand their limitation. These views help understand the status of Brazil from the perspective of British diplomats, but it should be acknowledged once again that they may be biased towards the status interests of the UK (Pouliot 2016).

\section{Conclusion}

The analysis of the external perceptions of the status and international agenda of Brazil according to British diplomats clearly demonstrates that there is an incongruence between what Brazil believes to be its place and role in international politics and what the foreign policy community in a country of higher status perceives as being this place and role. This is an important contribution to the study of the status of Brazil, since status is something that needs to be conferred and recognised by countries that are already seen as powerful (Murray 2019).

One of the main findings presented in the paper is the British perception that Brazil seems to want to be "friends with everyone" and, thus, avoids taking sides on any international dispute. It remains "on the fence" in important issues, which may hinder the legitimacy of its bid for a stronger voice in global politics. As much as Brazil wants to achieve international prestige, nations that hold higher status, such as the UK discussed here, see no reason to accept that Brazil has a stronger voice in international relations. They perceive the country as having too many internal problems and not having a clear idea of what it would do if it did achieve higher status.

With this analysis, this paper offers an important contribution to the study of status in international relations. Although the literature recognises the intersubjective characteristics of status and the importance of perceptions to understand the hierarchical differences of the standing of states vis-a-vis one another, most studies conducted so far have focused on what countries want to achieve and their strategies. While other researchers have tried to develop quantitative methods to measure status, the study presented here focused on status from the external perception, following a qualitative paradigm. Even if there are limitations to this method, it offers a different perspective to a new area of study of international relations that is heavily influenced by psychology. It draws on ideas of this application of psychology to IR, which tries to establish ways through which personal beliefs of actors within the foreign relations community, and perceptions about other nations, may influence the policy of states with high status.

\section{References}

Amancio, T. O Brasil dos gringos: imagens no cinema. Niterói, RJ: Intertexto, 2000. Andrade, L. C. "O Brasil em busca de um assento permanente no conselho de segurança: análise construtivista da política externa de 1945 a 2011.” Paper presented at Seminário Nacional de Pós-Graduação em Relaçóes Internacionais, Brasília, DF, July, 2012. 
Arraes, V. C. "O Brasil e o conselho de segurança da Organização das Naçóes Unidas: dos anos 90 a 2002." Revista Brasileira de Politica Internacional 48, no. 2 (2005): 152-168. doi: https://doi.org/10.1590/S0034-73292005000200008

Barkin, S. "'Qualitative' methods?" In Qualitative methods in international relations, edited by A. Klotz, and D. Prakash, 211-220. New York, NY: Springer, 2008.

Beaumont, P., and P. Røren. "Brazil's status struggles: why nice guys finish last.” In Status and the rise of Brazil, edited by P. Esteves, M. G. Jumbert, and B. Carvalho, 31-48. New York, NY: Springer, 2020.

Bignami, R. A imagem do Brasil no turismo: construção, desafios e vantagem competitiva. São Paulo, SP: Aleph, 2002.

Braun, V., and V. Clarke. Successful qualitative research: a practical guide for beginners. London: Sage, 2013.

Bryman, A. Social research methods. 4th ed. Oxford: Oxford University, 2012.

Buarque, D. "Brazil is not (perceived as) a serious country: exposing gaps between the external images and the international ambitions of the nation." Brasiliana: Journal for Brazilian Studies 8, no. 1-2 (2019): 285-314. doi: https://doi.org/10.25160/bjbs.v8i1-2.112957

Buarque, D. "One country, two cups: the international image of Brazil in 1950 and in 2014: a study of the reputation and the identity of Brazil as projected by the international media during the two FIFA world cups in the country." International Journal of Communication 9, (2015): 1300-1318.

Buarque, D. “The tainted spotlight: how crisis overshadowed Brazil's public diplomacy bet in hosting sports events and led to a downgrade of the country's reputation." Trama Interdisciplinar 8, no. 3 (2017). doi: https://doi.org/10.5935/2177-5672/trama.v8n3p71-92

Carvalho, B. "Brazil's (frustrated) quest for higher status." In Status and the rise of Brazil, edited by P. Esteves, M. G. Jumbert, and B. Carvalho, 19-30. New York, NY: Springer, 2020.

Chatin, M. "Brazil: analysis of a rising soft power." Journal of Political Power 9, no. 3 (2016): 369-393. doi: https://doi.org/10.1080/2158379X.2016.1232286

Chatin, M. "Brazil: a new powerhouse without military strength?” BRICS Policy Center Working Paper, January, 2013.

Clunan, A. L. "Why status matters in world politics." In Status in world politics, edited by T. V. Paul, D. W. Larson, and W. C. Wohlforth, 273-296. Cambridge: Cambridge University, 2014.

Diaz, M., and P. R. Almeida. Brazil's candidacy for major power status. Muscatine, IA: Stanley Foundation, 2008.

Duque, M. G. “Recognizing international status: a relational approach.” International Studies Quarterly 62, no. 3 (2018): 577-592. doi: https://doi.org/10.1093/isq/sqy001 
Garcia, E. V. "De como o Brasil quase se tornou membro permanente do conselho de segurança da ONU em 1945.” Revista Brasileira de Politica Internacional 54, no. 1 (2011): 159-177. doi: https://doi.org/10.1590/S0034-73292011000100010

Hamann, E. P., and M. G. Jumbert. "Brazil's evolving 'balancing act' on the use of force in multilateral operations: from robust peacekeeping to 'responsibility while protecting'." In Status and the rise of Brazil, edited by P. Esteves, M. G. Jumbert, and B. Carvalho, 153-173. New York, NY: Springer, 2020.

Hurrell, A. "Brazil and the new global order." Current History 109, no. 724 (2010): 60-66. doi: https://doi.org/10.1525/curh.2010.109.724.60

Jiménez-Martínez, C. "Which image? Of which country? Under which spotlight? Power, visibility, and the image of Brazil.” Trama Interdisciplinar 8, no. 3 (2018): 52-70. doi: https://doi.org/10.5935/2177-5672/trama.v8n3p52-70

Kaczmarski, M. "Quest for status: chinese and russian foreign policy." International Affairs 95, no. 5 (2019): 1188-1189. doi: https://doi.org/10.1093/ia/iiz148

Kajihara, K. A. "A imagem do Brasil no exterior: análise do material de divulgação oficial da Embratur, desde 1966 até 2008." Observatório de Inovação do Turismo 5, no. 3 (2010): 1-30. doi: https://doi.org/10.12660/oit.v5n3.5777

Kenkel, K. M., D. M. Souza Neto, and M. M. L. A. Ribeiro. "Peace operations, intervention and brazilian foreign policy: key issues and debates." In Status and the rise of Brazil, edited by P. Esteves, M. G. Jumbert, and B. Carvalho, 133-151. New York, NY: Springer, 2020.

Klotz, A. "Introduction." In Qualitative methods in international relations, edited by A. Klotz, and D. Prakash, 1-7. New York, NY: Springer, 2008.

Lafer, C. A identidade internacional do Brasil e a politica externa brasileira: passado, presente e futuro. São Paulo, SP: Perspectiva, 2001.

Lake, D. A. "Status, authority, and the end of the american century." In Status in world politics, edited by T. V. Paul, D. W. Larson, and W. C. Wohlforth, 246-272. Cambridge: Cambridge University, 2014.

Larson, D. W., and A. Shevchenko. "Managing rising powers: the role of status concerns." In Status in world politics, edited by T. V. Paul, D. W. Larson, and W. C. Wohlforth, 33-57. Cambridge: Cambridge University, $2014 \mathrm{a}$.

Larson, D. W., and A. Shevchenko. "Prestige matters: chinese and russian status concerns and U.S. foreign policy." Quarterly Journal: International Security, April, 2010. https://www.belfercenter.org/publication/prestige-matters-chinese-and-russian-statusconcerns-and-us-foreign-policy

Larson, D. W., and A. Shevchenko. "Russia says no: power, status, and emotions in foreign policy." Communist and Post-Communist Studies 47, no. 3-4 (2014b): 269-279. doi: https://doi.org/10.1016/j.postcomstud.2014.09.003

Larson, D. W., and A. Shevchenko. Quest for status: chinese and russian foreign policy. London: Yale University, 2019. 
Larson, D. W. "Status competition among Russia, India, and China in clubs: a source of stalemate or innovation in global governance." Contemporary Politics 25, no. 5 (2019): 549-566. doi: https://doi.org/10.1080/13569775.2019.1622183

Lebow, R. N. A cultural theory of international relations. Cambridge: Cambridge University, 2008.

Lebow, R. N. National identities and international relations. Cambridge: Cambridge University, 2016.

Malamud, A. "A leader without followers? The growing divergence between the regional and global performance of brazilian foreign policy." Latin American Politics and Society 53, no. 3 (2011): 1-24. doi: https://doi.org/10.1111/j.1548-2456.2011.00123.x

Mares, D. R., and H. A. Trinkunas. Aspirational power: Brazil on the long road to global influence. Washington, DC: Brookings Institution, 2016.

Mariutti, F., and R. Tench. "How does Brazil measure up? Comparing rankings through the lenses of nation brand indexes." Place Branding and Public Diplomacy 12, no. 1 (2016): 17-31. doi: https://doi.org/10.1057/pb.2015.19

Mariutti, F., R. Tench, J. M. E. Giraldi, and M. G. Montanari. "'If I huff and I puff': foundations for building Brazil's image: evidence from an international systematic review (2001 to 2015).” Internext 12, no. 2 (2017): 58-73. doi: https://doi.org/10.18568/1980-4865.12258-73

Markey, D. "Prestige and the origins of war: returning to realism's roots." Security Studies 8, no. 4 (1999): 126-172. doi: https://doi.org/10.1080/09636419908429388

Mendes, F. P. "O Brasil e a reforma do conselho de segurança: uma análise realista." Contexto Internacional 37, no. 1 (2015): 113-142. doi: https://doi.org/10.1590/S0102-85292015000100004

Mercer, J. “The illusion of international prestige." International Security 41, no. 4 (2017): 133-168. doi: https://doi.org/10.1162/ISEC_a_00276

Murray, M. "Identity, insecurity, and great power politics: the tragedy of german naval ambition before the first world war." Security Studies 19, no. 4 (2010): 656-688. doi: https://doi.org/10.1080/09636412.2010.524081

Murray, M. The struggle for recognition in international relations: status, revisionism, and rising powers. New York, NY: Oxford University, 2019.

Neumann, I. B. "Status is cultural: durkheimian poles and weberian russians seek great-power status." In Status in world politics, edited by T. V. Paul, D. W. Larson, and W. C. Wohlforth, 85-112. Cambridge: Cambridge University, 2014.

Neumann, I. B., and B. Carvalho. "Introduction: small states and status." In Small states and status seeking: Norway's quest for international standing, edited by I. B. Neumann, and B. Carvalho. New York, NY: Routledge, 2014.

Pant, H. V. “The Brics fallacy.” The Washington Quarterly 36, no. 3 (2013): 91-105. doi: https://doi.org/10.1080/0163660X.2013.825552. 
Paul, T. V., and M. Shankar. "Status accommodation through institutional means: India's rise and the global order." In Status in world politics, edited by T. V. Paul, D. W. Larson, and W. C. Wohlforth, 165-191. Cambridge: Cambridge University, 2014.

Paul, T. V., D. W. Larson, and W. C. Wohlforth. Status in world politics. Cambridge: Cambridge University, 2014.

Pouliot, V. International pecking orders: the politics and practice of multilateral diplomacy. Cambridge: Cambridge University, 2016.

Pouliot, V. "Setting status in stone: the negotiation of international institutional privileges." In Status in world politics, edited by T. V. Paul, D. W. Larson, and W. C. Wohlforth, 192-215. Cambridge: Cambridge University, 2014.

Renshon, J. Fighting for status: hierarchy and conflict in world politics. Princeton, NJ: Princeton University, 2017.

Ricupero, R. A diplomacia na construção do Brasil 1750-2016. Rio de Janeiro, RJ: Versal, 2017.

Røren, P., and P. Beaumont. "Grading greatness: evaluating the status performance of the Brics." Third World Quarterly 40, no. 3 (2019): 429-450. doi: https://doi.org/10.1080/01436597.2018.1535892.

Souza, A. A agenda internacional do Brasil: um estudo sobre a comunidade brasileira de politica externa. Rio de Janeiro, RJ: Centro Brasileiro de Relações Internacionais, 2002.

Souza, A. Brazil's international agenda revisited: perceptions of the brazilian foreign policy community. Rio de Janeiro, RJ: Centro Brasileiro de Relaçôes Internacionais, 2008.

Stolte, C. Brazil's Africa strategy. New York, NY: Palgrave, 2015.

Stuenkel, O., and M. M. Taylor. Brazil on the global stage: power, ideas, and the liberal international order. New York, NY: Palgrave, 2015.

Vargas, J. A. C. "Persuadir e legitimar: a argumentação brasileira em favor da reforma do conselho de segurança." Cena Internacional 10, no. 2 (2008): 119-138.

Volgy, T. J., R. Corbetta, K. A. Grant, and R. G. Baird. "Major power status in international politics." In Major powers and the quest for status in international politics, edited by T. J. Volgy, R. Corbetta, K. A. Grant, and R. G. Baird, 1-26. New York, NY: Palgrave, 2011.

Volgy, T. J., R. Corbetta, J. P. Rhamey, R. G. Baird, and K. A. Grant. "Status considerations in international politics and the rise of regional powers." In Status in world politics, edited by T. V. Paul, D. W. Larson, and W. C. Wohlforth, 58-84. Cambridge: Cambridge University, 2014.

Wendt, A. "Anarchy is what states make of it: the social construction of power politics." International Organization 46, no. 2 (1992): 391-425. doi: https://doi.org/10.1017/S0020818300027764

Wendt, A. Social theory of international politics. Cambridge: Cambridge University, 2003. Wendt, A. "The state as person in international theory." Review of International Studies 30, no. 2 (2004): 289-316. doi: https://doi.org/10.1017/S0260210504006084. 
Wohlforth, W. C., B. Carvalho, H. Leira, and I. B. Neumann. "Moral authority and status in international relations: good states and the social dimension of status seeking." Review of International Studies 44, no. 3 (2018): 526-546. doi: https://doi.org/10.1017/S0260210517000560

Wohlforth, W. C. "Status dilemmas and interstate conflict." In Status in world politics, edited by T. V. Paul, D. W. Larson, and W. C. Wohlforth, 115-140. Cambridge: Cambridge University, 2014.

Wolf, R. "Respect and disrespect in international politics: the significance of status recognition." International Theory 3, no. 1 (2011): 105-142. doi: https://doi.org/10.1017/S1752971910000308

Wolf, R. "Taking interaction seriously: asymmetrical roles and the behavioral foundations of status." European Journal of International Relations 25, no. 4 (2019): 1186-1211. doi: https://doi.org/10.1177/1354066119837338

Wolfers, A. "The actors in international politics." In Discord and collaboration: essays on international politics, edited by A. Wolfers, 3-24. Baltimore, MD: Johns Hopkins University, 1962. 